\title{
CORRELATION BETWEEN SERUM ZINC LEVEL AND ERYTHROCYTE SUPEROXIDE DISMUTASE (SOD) ACTIVITY IN NON-FRAIL AND FRAIL GERIATRIC PATIENTS
}

\author{
Rosnah Pinontoan, ${ }^{1}$ Savitri Sayogo, ${ }^{1}$ Arya Govinda Roosheroe ${ }^{2}$ \\ 1 Department of Clinical Nutrition, Faculty of Medicine, Universitas Indonesia \\ 2 Division of Geriatry, Department of Internal Medicine, Cipto Mangunkusumo Hospital, Jakarta, Indonesia
}

Abstract-Introduction: Frailty syndrome (FS), as a health problem in elderly, can interfere with the quality of life. Many factors play roles in its occurrence, one of which is oxidative stress. Superoxide dismutase (SOD), in which one of its components is zinc $(\mathrm{Zn})$, is one of the endogenous antioxidants that plays a role in preventing oxidative stress. This study was aimed to know the correlation between serum zinc level (sZn) and erythrocyte SOD (eSOD) activity in non-frail and frail geriatric patients.

Methods: This was cross-sectional study with consecutive sampling method conducted in the Geriatric Clinic Cipto Mangunkusumo hospital, from August through September 2014, on 60 patients (30 patients for each group of non-frail and frail). Data were collected from interviews, physical measurements, and venous blood sampling.

Results: Among $90 \%$ of the subjects had low $\mathrm{Zn}$ intake, at the same time, the mean of sZn was 8.41 $\pm 1.36 \mathrm{~mol} / 1$ and $93.3 \%$ of the subjects had experienced $\mathrm{Zn}$ deficiency. The mean of eSOD activity was $1526 \pm 508 \mathrm{U} / \mathrm{gHb}$, and there was no significant difference between the groups. There were no significant correlation between $\mathrm{sZn}$ and eSOD activity both in the overall subject $(r=-0.04$; $\mathrm{p}=0.076)$, as well as the non-frail group $(\mathrm{r}=$ $0.099 ; \mathrm{p}=0.604)$ and frail group $(\mathrm{r}=0.01 ; \mathrm{p}=$ $0.957)$.

Conclusion: Serum zinc level did not have any significant correlation with the eSOD activity, neither on overall or both non-frail and frail groups.

Keywords: geriatric patient, serum zinc level, erythrocyte SOD activity, frailty syndrome

\section{INTRODUCTION}

Aging process is a natural process with the downward trend in the functional capacity, which occurs continuously at the molecular, cellular, and organ level. Lowering in the body functional capacity affects the occurrence of certain health problems, such as the frailty syndrome. ${ }^{1,2}$

Frailty syndrome is a clinical syndrome caused by the accumulation of the aging process, physical inactivity, weight loss, inadequate chronic intake, lifestyle, and unhealthy environment. ${ }^{1}$ These factors are interrelated and endwith decreasein muscle and bone mass. ${ }^{3,4}$ Sarcopenia plays an important role in the occurrence of frailty syndrome; which is marked with a condition of loss of skeletal muscle mass and strength due to the aging process. ${ }^{3,5}$ Pathogenesis of sarcopenia is multifactorial, including malnutrition, nutritional oxidative stress, inflammation, hormonal changes, physical inactivity, and genetic factors. ${ }^{5}$

Naturally, the human body produces reactive oxygen species (ROS) which are prooxidants and on the other hand has a defense mechanism to cope with the damage that is caused by free radicals through the work of antioxidants, either endogenous or exogenous. ${ }^{6}$ In the aging process, the ability of antioxidant defense mechanism is decreased, caused by a decrease in endogenous antioxidants, one of which is the enzyme superoxide dismutase (SOD); and contributes to the occurrence of sarcopenia., ${ }^{5,6}$

Zinc is one of the minerals that plays an important role in maintaining metabolic homeostasis and antioxidant mechanisms, ${ }^{7,8}$ which is also an important part in a variety of protein structures of the body, including the role of zinc in the SOD to maintain the stability of the structure, especially isoform CuZnSOD. ${ }^{9}$

Various studies concerning the correlation between serum zinc level and eSOD activity showed no consistent results. A weak negative correlation between serum zinc level and eSOD activity was shown in few healthy elderly subjects. Zinc supplementation increases eSOD activity. ${ }^{10}$ Nonetheless, other studies in healthy elderly 
subjects showed no correlation between zinc level and SOD activity. ${ }^{7}$

Most studies were done in healthy elderly subjects. There are still no data concerning the correlation between zinc level and eSOD activity in elderly patients with frailty syndrome, especially in Indonesia. This study aimed to determine the correlation between serum zinc level (sZn) and erythrocyte SOD (eSOD) activity in non-frail and frail geriatric patients.

\section{METHODS}

\section{Design and Subjects}

This is a cross-sectional study aimed to determine the correlation between serum zinc level and erythrocyte SOD activity in non-frail and frail geriatric patients, which was conducted at Cipto Mangunkusumo Geriatric Clinic from mid-August 2014 through mid-September 2014. The Ethics Committee from the Faculty of Medicine, Universitas Indonesia, had approved this study. The number of subjects, (this study used $\mathrm{r}=0.5 ; \beta=0.1$; and $\alpha=0.05$ ), including $10 \%$ chance of drop-out was 30 for each non-frail and frail group. ${ }^{11} \mathrm{~A}$ total of 60 geriatric patients, who participated in this study, signed an informed consent, and completed the study.

Frailty syndrome status is determined based on the index Frailty 40 items by research assistants of the Geriatric Division of Internal Medicine Department of Faculty of Medicine of Universitas Indonesia. The inclusion criteria were all elderly patients in the geriatric clinic who were given an informed consent and agreed to participate in this study. The exclusion criteria were as follows: having acute infection, intestinal disorder, and cognitive status disorder by Mini Mental State Examination scores $<24$.

\section{Study Measurements}

The design was cross sectional study, which was done in the geriatric clinic in Cipto Mangunkusumo General Hospital, Jakarta, Indonesia. Data were collected consecutively from August to September 2014, by trained research assistants. Data werecollected from interviews for demographic characteristics, anthropometric measurements including body weight and knee height, evaluation of food intake with $3 \times 24$ hours estimated food record method for macronutrient assessment, and semiquantitative food frequency questionnaire (FFQ) for zinc intake assessment. Volumes and portion sizes for $3 \times 24$ hours food record and semiquantitative FFQ were estimated using photographs and food models. Intake data were analyzed using Nutrisurvey 2007 program for Windows operating system.

Nutritional status was evaluated based on body mass index (BMI) for Asia-Pacific population. ${ }^{12}$ Body mass index was calculated as weight $(\mathrm{kg})$ divided by height $\left(\mathrm{m}^{2}\right)$. Weight was measured with minimum clothing using platform SECA, meanwhile height was determined by knee height using knee height measuring instrument. ${ }^{13}$

Venous blood sampling was performed for serum zinc level and erythrocyte SOD activity. Serum zinc levels was determined by atomic absoprtion spectrophotometry method, while erythrocyte SOD activity was determined by using colorimetry method. ${ }^{14}$ This study used cut-off values of 10.1 $\mu \mathrm{mol} / \mathrm{l}$ serum zinc deficiency level for females and $10.7 \mu \mathrm{mol} / 1$ for males. While erythrocyte SOD activity normal range was $1102-1601 \mathrm{U} / \mathrm{g} \mathrm{Hb}$.

\section{Statistical Analysis}

All data were analyzed using Statistical Package for Social Science (SPSS) version 20 for Windows operating system. Kolmogorov-Smirnov normality test was done to the numeric data of the total subjects, while Shapiro Wilk test was done to numeric data of each group (frail and non-frail group). For data which were normally distributed according to normality test, Pearson bivariate analysis was done to determine the correlation between serum zinc level and eSOD activity. If not normally distributed, Spearman rank test was used. Significance level used was $\mathrm{p}<0.05$.

\section{RESULTS}

All subjects completed all procedures used in the study, the characteristics of the demographic and nutrition status data is shown in Table 1. The mean age was $72.6 \pm 6.5$ years with the highest percentage in the age range $70-79$ years $(55.0 \%)$. Mean BMI was $24.41 \pm 4.69 \mathrm{~kg} / \mathrm{m}^{2}$, with only $3.3 \%$ of the subjects classified as underweight and most of the subjects $(61.7 \%)$ were in the overweight category, meanwhile obese II subjects $(10 \%)$ were 
only found in the frail group. There were significant $\quad 2.791 \mathrm{~kg} / \mathrm{m}^{2}(\mathrm{CI} 95 \%=-5.132-(-0.450)$ higher in differences in BMI between the groups, which was the frail group. 
Tabel 1. Demographic, Nutrition, Macronutrient and Zinc Intake Status of the Subjects

\begin{tabular}{|c|c|c|}
\hline Characteristic & Frequency (n) & Percentage (\%) \\
\hline \multicolumn{3}{|l|}{ Age (year) } \\
\hline $60-69$ & 19 & 31.7 \\
\hline $70-79$ & 33 & 55.0 \\
\hline$>80$ & 8 & 13.3 \\
\hline \multicolumn{3}{|l|}{ Gender } \\
\hline Male & 26 & 43.3 \\
\hline Female & 34 & 56.7 \\
\hline \multicolumn{3}{|l|}{ Nutrition Status (BMI) } \\
\hline Underweight & 2 & 3.3 \\
\hline Normal Weight & 21 & 35.0 \\
\hline \multicolumn{3}{|l|}{ Overweight } \\
\hline High Risk & 16 & 26.7 \\
\hline Obese I & 15 & 25.0 \\
\hline Obese II & 6 & 10.0 \\
\hline \multicolumn{3}{|l|}{ Nutrient Intake } \\
\hline \multicolumn{3}{|l|}{ Energy } \\
\hline$<90 \%$ TER* & 31 & 51.7 \\
\hline $90-110 \%$ TER & 14 & 23.3 \\
\hline$>110 \%$ TER & 15 & 25.0 \\
\hline \multicolumn{3}{|l|}{ Protein } \\
\hline$<10 \%$ TER & 18 & 30.0 \\
\hline $10-15 \%$ TER & 24 & 40.0 \\
\hline$>15 \%$ TER & 18 & 30.0 \\
\hline \multicolumn{3}{|l|}{ Fat } \\
\hline$<20 \%$ TER & 1 & 1.70 \\
\hline $20-30 \%$ TER & 27 & 45.0 \\
\hline$>30 \%$ TER & 32 & 53.3 \\
\hline \multicolumn{3}{|l|}{ Zinc } \\
\hline < Indonesian RDA** 2013 & 54 & 90.0 \\
\hline Indonesian RDA 2013 & 3 & 5.0 \\
\hline > Indonesian RDA 2013 & 3 & 5.0 \\
\hline
\end{tabular}

*TER = total energy requirement; **RDA = recommended daily allowance

Table 2. Characteristic of Subject's Serum Zinc level and Erythrocyte SOD Activity Based on Frailty Status

\begin{tabular}{llll}
\hline & \multicolumn{3}{c}{ Subject } \\
\cline { 2 - 4 } & Non-Frail $(\mathrm{n}=30)$ & Frail $(\mathrm{n}=30)$ & Total $(\mathrm{n}=60)$ \\
\hline sZn Level & $3(10 \%)$ & $1(3.3 \%)$ & $4(6.7 \%)$ \\
Normal & $27(90 \%)$ & $29(96.7 \%)$ & $56(93.3 \%)$ \\
Deficiency & & & \\
eSOD Activity & $13(43.3 \%)$ & $14(46.7 \%)$ & $27(45 \%)$ \\
High & $10(33.3 \%)$ & $11(36.7 \%)$ & $21(35 \%)$ \\
Normal & $7(23.3 \%)$ & $5(16.7 \%)$ & $12(20 \%)$ \\
Low & &
\end{tabular}

Median energy intake was 86.97 (51.8-58.84)\% 
Table 3. Correlation between Serum Zinc Levels and Erythrocyte SOD Activity

\begin{tabular}{lcc}
\hline \multicolumn{1}{c}{ Subject } & $\mathrm{r}$ & $\mathrm{p}$ \\
\hline Overall (n=60) & $-0,04$ & 0,076 \\
Non-Frail & $-0,099$ & 0,604 \\
Frail & 0,01 & 0,957 \\
\hline
\end{tabular}

total energy requirement (TER), low energy intake was found in $51.7 \%$ of the subjects. While the

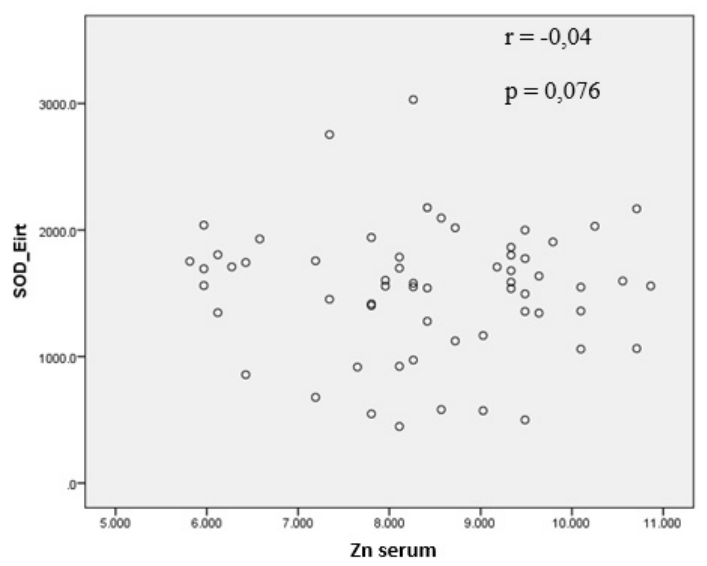

Figure 1. Correlation between sZn level and eSOD Activity in Subjects

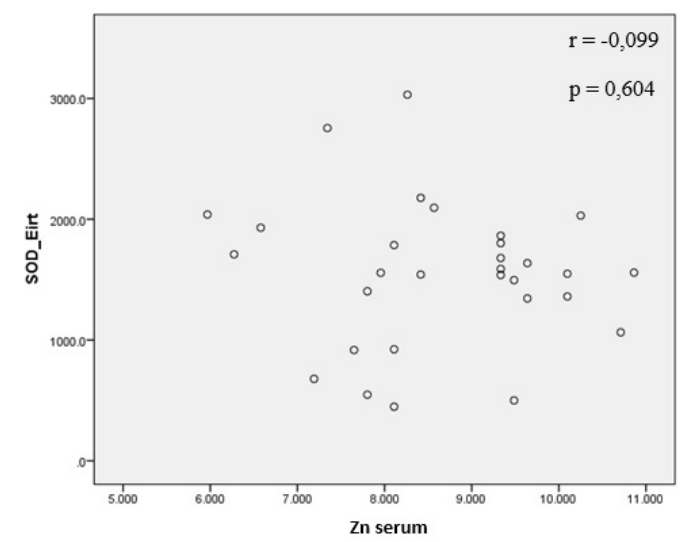

Figure 2. Correlation between sZn level and eSOD Activity in Non-frail Group median intake of protein was $12.14(3.39-50.66) \%$ TER, there was no difference in energy and protein intake between the two groups. Despite $51.7 \%$ of the subjects had low energy intake, $53.3 \%$ of the subjects had fat intake $>30 \%$ TER, with a mean value of fat intake of $32.5 \pm 8.19 \%$ TER, with no differences neither between the frail nor non-frail group nor among BMI groups.

Median of zinc intake, determined by semiquantitative FFQ method, was $4.99 \mathrm{mg}$ (2.50$15.76 \mathrm{mg}$ ), when compared with the Indonesian recommended daily allowance (RDA) 2013, 90\% of the subjects had zinc intake below the recommendation. The median intake of zinc in both groups was not significantly different, although the intake of the frail group (4.60 (2.50-11.0) $\mathrm{mg})$ was lower than the non-frail (6.52 (2.79-15.8) $\mathrm{mg})$. The characteristic of subjects based on energy, protein, fat, and zinc intake is shown in Table 1.

Mean sZn level was $8.41 \pm 1.36 \mu \mathrm{mol} / \mathrm{l}$, which $93.3 \%$ of the subjects categorized as zinc deficient (45\% in non-frail group vs $48.3 \%$ in frail group). The mean of eSOD activity was $1526 \pm 508 \mathrm{U} / \mathrm{gHb}$, while the mean eSOD activity of both groups was $1551 \pm 599 \mathrm{U} / \mathrm{gHb}$ and $1501 \pm 405 \mathrm{U} / \mathrm{gHb}$. There were no significant differences, neither in the mean of sZn level $(\mathrm{p}=0.174)$ nor eSOD activity $(\mathrm{p}=$ 0.707 ) between both groups.

There was no significant correlation found among age with sZn level and eSOD activity of the subjects, both overall as well as per group. There was no significant correlation between sZn level and eSOD activity, neither overall nor per group (Table 3).

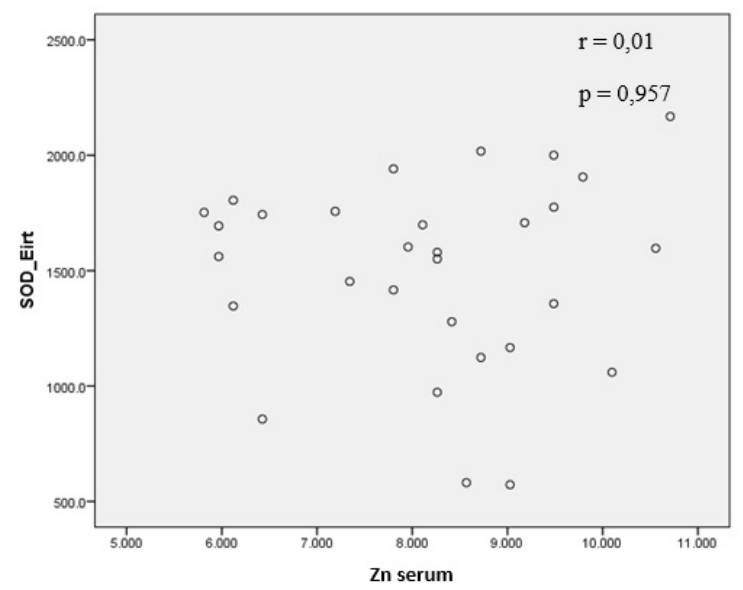

Figure 3. Correlation between $\mathrm{sZn}$ level and eSOD Activity in Frail Group

\section{DISCUSSION}

In this study, $61.7 \%$ of the subjects were classified as overweight, even $10 \%$ of subjects were obese II. The elderly rarely perform regular minimum recommended physical activity; moderate intensity for $5 \times 30$ minutes at least per week; only $22 \%$ of 
the elderly who have continuous sports activities. ${ }^{15}$ Sedentary lifestyle often occur in the elderly, due to physiological changes, such as the decreased organ capacity, and reduced muscle strength. ${ }^{15,16}$

The difference in mean BMI between the non-frail vs frail group is 2.79 , which was higher in the frail group. Other physiological changes in the elderly, like body composition changes, increased fat and visceral fat mass, decrease in muscle mass and body metabolic rate, were found. ${ }^{15}$ Excessive fat mass and loss of muscle mass, a condition called sarcopenic obesity, ${ }^{15}$ together with excess body weight causes a decrease in muscle strength, functional capacity in daily activities. ${ }^{4,15}$ Overweight and sedentary lifestyle accelerate the occurence of sarcopenia, and ultimately increase the incidence of frailty syndrome. ${ }^{15}$

Food record concluded $51,7 \%$ of the subjects had low energy intake, it should be considered that elderly intake of food is reduced up to $25 \%$ compared to adults, caused by the physiological changes in the elderly. ${ }^{15,17,18}$ In this study, $30 \%$ of the subjects had low protein intake, and we also should be concerned in terms of the quality of protein which is consumed by the subjects. Essential amino acids in animal protein is more complete than vegetable protein, also vegetable protein is bound to carbohydrates therefore it is more difficult to digest due to the limitations of the human digestive enzymes. ${ }^{19}$ Although $51.7 \%$ of the subjects had low energy intake, on the other hand $53.3 \%$ of the subjects had fat intake $\quad>30 \%$ TER and only 1 subject had a low fat intake $(<20 \%$ TER). Overweight in the elderly was not caused by a high intake of fat, but it is referring to the lack of the subject's physical activity (in this study we did not explore it further). The main therapy in obesity is weight loss without causing a decrease in muscle mass and increased risk of frailty, with physical exercise and adequacy of dietary protein, vitamins, and minerals, that without causing any increase in the amount of calories. $^{20}$

In this study, 93,3\% of the subjects had zinc deficiency, which is in line with the most of the subjects $(90 \%)$ had a lower zinc intake compared with Indonesian RDA 2013 (13 mg/day for males and $10 \mathrm{mg}$ /day for females). The result is consistent with several studies in other countries which were done in elderly subjects. A cross sectional study by
Mariani et $\mathrm{al}^{21}$ in 981 healthy elderly subjects showed $69 \%$ of the subjects had zinc deficiency (plasma zinc level $<10 \mu \mathrm{M}$ ). A study by Sfar et $\mathrm{al}^{7}$ showed a prevalence of zinc deficiency in elderly (age $>75$ years old) of $65 \%{ }^{7}$ The study also showed that the mean plasma zinc level in healthy adults (age 30-40 years old) was $11.75 \pm 1.65 \mu \mathrm{mol} / \mathrm{L}$.

The subjects are not used to consume animal foods, either meat or seafood which are food sources of zinc. Degenerative disease suffered by the subjects (dyslipidemia, hypertension, diabetes mellitus, and hyperuricemia) is also an obstacle for the subjects to consume these foods. Zinc is found in all organs, tissues, and body fluids, as well as having various biologic functions. Homeostasis of zinc keeps plasma zinc level in a small range, therefore a decrease in plasma/serum zinc concentration serum showed zinc deficiency in individuals, especially in relation to long term low zinc intake. ${ }^{22}$ In case of low zinc intake, enzymes containing zinc in plasma and metallothionin will be releasing zinc into the pool of zinc, and zinc will subsequently be distributed to other parts that are more in need of zinc. ${ }^{23}$

There are only few studies concerning SOD activity in elderly patients with frailty syndrome. A study in mice with knocked out SOD1 gen (SOD1KO) found that they had increased inflammation and sarcopenia, and also showed characteristics similar to frailty syndrome in humans which includes: weight loss, weakness, low physical activity, and exhaustion. The SOD1KO mice showed alterations in pathways that have been proposed to play roles in the patophysiology of frailty syndrome, which are oxidative stress, mitochondrial dysfunction, and cell senescence. ${ }^{24}$ In the present study, there was no differences in erythrocyte SOD activity between the non-frail and frail groups. Meanwhile, $45 \%$ of subjects had high erythrocyte SOD activity, and $20 \%$ had low erythrocyte SOD activity. High activity of erythrocyte SOD is a response to high pro oxidant/ROS stimulation in the cells, as well as vice versa. ${ }^{25}$ High pro oxidant can be due to various conditions, such as aging process, inflammation, anemia, free radicals, and obesity. ${ }^{25-29}$ In this study, $33.3 \%$ subjects had altered kidney function, which may be caused by anemia in chronic disease and thus contribute to increased pro inflammation. Another factor that may increase ROS level in cells 
is obesity. ${ }^{29}$ In this study, mean BMI was higher in the frail compared to the non-frail group $(p=0.02)$. In fact, $20 \%$ subjects in the frail group had class II obesity (BMI $\left.\geq 30 \mathrm{~kg} / \mathrm{m}^{2}\right)$.

This study did not show any significant correlation between serum zinc level and erythrocyte SOD activity. An in vitro experiment study in tissues, which were made to be zinc deficient, showed altered antioxidant defense mechanism in terms of decreased SOD activity. ${ }^{30}$ The result of the in vitro study was different from our study, which may be due to compensation mechanism from free zinc pool and bound zinc which maintain zinc-related enzyme function. Studies in animal or human subjects still have not shown consistent results in the correlation between zinc status and SOD activity. ${ }^{7,31-34}$ The inconsistent result may be due to insufficient number of subjects. ${ }^{21}$ A study by Mariani et $\mathrm{al}^{21}$ with a greater number of subjects $(\mathrm{n}=981)$ showed weak yet significant negative correlation between zinc level and SOD activity $(\mathrm{r}=-0.1 ; \mathrm{p}<0.01)$. However, other studies involving other trace element status (e.g Cuprum) showed correlation with SOD activity. ${ }^{32}$

Activity of SOD is influenced by many factors, such as free radicals, inflammation due to degenerative disease, and obesity. These confounding factors of SOD activity were not controlled in this study. Otherwise zinc as part of the structure of the CuZnSOD enzyme, in which the role of zinc is a stabilizer of the structure, can be replaced by other metals when the body is deficient. The role of zinc could be replaced by cuprum $(\mathrm{Cu})$ or cobalt $(\mathrm{Co}),{ }^{35}$ it was probably the reason why the SOD activity can be increased even in the case of zinc deficiency, as it did in the subjects of this study.

In conclusion, in this study serum zinc level did not significantly correlate with erythrocyte SOD activity both overall and per group.

\section{Study Limitation}

This study had several limitations. Because it was a cross sectional design, the direction of the reported associations cannot be established. A cross sectional study does not have controls, and is susceptible to bias and confounding factors.

Dietary assessment is challenging in elderly, their abilities to record and remember their diet is limited. Under reporting of dietary analysis, which was performed by semi quantitative FFQ and $3 \times 24$ hours estimated food record, may be another limitations in this study. Using serum zinc level may not reflect total body zinc level, due to serum zinc level only shows less than $0.1 \%$ of body zinc.

The measurement of a single endogen antioxidant activity, which is erythrocyte SOD, was performed in this study, while other major endogenous enzymes were not examined. Fluctuations in the activity of endogen antioxidant enzymes are responsive to pro oxidant stimulation in the body, so that the level of other endogen antioxidants and oxidative stress markers need to be assessed. Further research with larger number of subjects and also considering other endogen antioxidants, oxidative stress marker, and trace elements may be needed to determine the correlation between zinc and SOD activity in elderly patients, especially in frailty syndrome.

\section{Conflicts of Interest}

The authors of this paper declare there is no conflict of interest.

\section{Acknowledgment}

We would like to thank all the staff of Division of Geriatry, Department of Internal Medicine, in Cipto Mangunkusumo Hospital, Jakarta, Indonesia, who had helped in this research.

\section{REFERENCES}

1. Setiati S, Murti KH, Roosheroe AG. Proses menua dan Implikasi Klinis. In: Sudoyo AW, Setiyohadi B, Alwi I, Simadibrata M, Setiati S (editor) Buku Ajar Ilmu Penyakit Dalam. 11th ed. Jakarta: FKUI; 2006. p. $1345-50$.

2. WHO | Facts about ageing [Internet]. [cited 2014 Jan 5]. Available from:

http://who.int/ageing/about/facts/en/

3. Seto E, Setiati S, Laksmi PW, Tamin TZ. Diagnostic Test of a Scoring System for Frailty Syndrome in the Elderly According to Cardiovascular Health Study, Study of Osteoporotic Fracture and Comprehensive Geriatric Assessment Based Frailty Index Compared with Frailty Index 40 Items. Acta Medica Indones. 2015 Jul;47(3):183-7.

4. Lang P-O, Michel J-P, Zekry D. Frailty syndrome: a transitional state in a dynamic process. Gerontology. 2009;55(5):539-49.

5. Semba RD, Lauretani F, Ferrucci L. Carotenoids as protection against sarcopenia in older adults. Arch Biochem Biophys. 2007 Feb 15;458(2):141-5. 
6. Jackson MJ. Control of reactive oxygen species production in contracting skeletal muscle. Antioxid Redox Signal. 2011 Nov 1;15(9):2477-86.

7. Sfar S, Jawed A, Braham H, Amor S, Laporte F, Kerkeni A. Zinc, copper and antioxidant enzyme activities in healthy elderly Tunisian subjects. Exp Gerontol. 2009 Dec;44(12):812-7.

8. Mocchegiani E. Zinc and ageing: third Zincage conference. Immun Ageing A. 2007 Sep 20;4:5.

9. Johnson F, Giulivi C. Superoxide dismutases and their impact upon human health. Mol Aspects Med. 2005 Oct;26(4-5):340-52.

10. Mariani E, Mangialasche F, Feliziani FT, Cecchetti $\mathrm{R}$, Malavolta M, Bastiani P, et al. Effects of zinc supplementation on antioxidant enzyme activities in healthy old subjects. Exp Gerontol. 2008 May;43(5):445-51.

11. Madiyono B, Moeslichan S, Sastroasmoro S, Budiman I,Purwanto SH. Perkiraan Besar Sampel. In: Sastroasmoro S, Ismael S, Editor Dasar-dasar Metodologi Penelitian Klinis. 4th ed. Jakarta: Sagung Seto; 2011. p. 348-81.

12. WPRO | The Asia Pacific perspective: Redefining obesity and its treatment [Internet]. WPRO. [cited 2014 Jan 19]. Available from: http:/www.wpro.who.int/nutrition/documents/Redefi ning obesity/en/

13. Shahar S, Pooy NS. Predictive equations for estimation of stature in Malaysian elderly people. Asia Pac J Clin Nutr. 2003;12(1):80-4.

14. Sauberlich HE. Assessment of Nutritional Status. 2nd ed. USA: CRC Press; 1999.

15. Wellman NS, Kamp BJ. Nutrition in Aging. In: Mahan LK, Escott-Stump S, Raymond JL, Editor Krause,s Foodand Nutrition Care Process. 13th ed. USA: Elsevier; 2012. p. 442-59.

16. Ireton-Jones CS. Intkae: Energy. In: Mahan LK, Escott-Stump S, Raymond JL, Editor Krause, $\mathrm{s}$ Foodand Nutrition Care Process. 13th ed. USA: Elsevier; 2012. p. 19-31.

17. Martini RD. Tatalaksana Nutrisi pada Frailty Usia Lanjut. In: Dwimartutie N, Rizka A, Editor Temu Ilmiah Geriatri 2014 Primary and Advanced Geriatric Care Care-Based Approach. Jakarta: PGMI; 2014. p. 20-7.

18. Aryana IGSP. Peran Diet untuk Sarkopenia pada Orang Usia Lanjut. In: Setiati S, Laksmi PW, Martutie N, Rizka A, Editor Temu Ilmiah Geriatri 2012 Evidence-Based Practice in Geriatric Medicine. Jakarta: PGMI; 2012. p. 110-8.

19. Gallagher ML. Intae: The Nutrients and Their Metabolism: Zinc. In: Mahan LK, Escott-Stump S, Raymond JL, Editor Krause,s Foodand Nutrition Care Process. 13th ed. USA: Elsevier; 2012. p. 1114.

20. Aryana IGSP. Obesitas pada Orang Usia Lanjut. In: Setiati S, Laksmi PW, Martutie N, Rizka A, Editor Temu Ilmiah Geriatri 2012 Evidence-Based Practice in Geriatric Medicine. Jakarta: PGMI; 2012. p. 1108.
21. Mariani E, Cornacchiola V, Polidori MC, Mangialasche F, Malavolta M, Cecchetti R, et al. Antioxidant enzyme activities in healthy old subjects: influence of age, gender and zinc status: results from the Zincage Project. Biogerontology. 2006;7(56):391-8.

22. King JC, Cousins RJ. Zinc. In: Ross AC, Caballero B, Cousins RJ, Tucker KL, Ziegler TR, Editor Modern Nutrition in Health and Disease. 11th ed. China: Lippincott Williams and Wilkins; 2014. p. 189-205.

23. Gropper SS, Smith JL. Advance Nutrition and Human Metabolism. 6th ed. Canada: Wadsworth; 2013.

24. Deepa SS, Bhaskaran S, Espinoza S, Brooks SV, McArdle A, Jackson MJ, et al. A new mouse model of frailty: the $\mathrm{Cu} / \mathrm{Zn}$ superoxide dismutase knockout mouse. GeroScience. 2017 Apr 1;39(2):187-98.

25. Kasapoglu M, Ozben T. Alterations of antioxidant enzymes and oxidative stress markers in aging. Exp Gerontol. 2001 Feb;36(2):209-20.

26. Kirkwood TBL, Mathers JC. The Basic Biology in Ageing. In: Stanner S, Thompson R, Buttriss JL, Editor Healthy Ageing The Role of Nutrition and Lifestyle. Singapore: Wiley-Blackwell; 2009. p. 2635 .

27. Baratawidjaja KG, Rengganis I. Imunologi Dasar. 11th ed. Jakarta: FKUI; 2014.

28. Kocyigit A. Erel O,Gus S. Effects of Tobacco Smoking on Plasma Selenium, Zinc, Copper, and Iron concentration and Related Antioxidative Enzyme Activities. Clin Biochem. 2001;34:629-33.

29. Fernández-Sánchez A, Madrigal-Santillán E, Bautista M, Esquivel-Soto J, Morales-González A, EsquivelChirino $\mathrm{C}$, et al. Inflammation, oxidative stress, and obesity. Int J Mol Sci. 2011;12(5):3117-32.

30. Oteiza PI, Olin KL, Fraga CG, Keen CL. Zinc deficiency causes oxidative damage to proteins, lipids and DNA in rat testes. J Nutr. 1995 Apr;125(4):8239.

31. Chakraborty I, Kunti S, Bandyopadhyay M, Dasgupta A, Chattopadhyay GD, Chakraborty S. Evaluation of serum zinc level and plasma SOD activity in senile cataract patients under oxidative stress. Indian J Clin Biochem. 2007 Sep;22(2):109-13.

32. Bettger WJ, Taylor CC. Effects of copper and zinc status of rats on the concentration of copper and zinc in the erythrocyte membrane. Nutr Res. 1986 Apr $1 ; 6(4): 451-7$.

33. Coudray C, Richard MJ, Laporte F, Faure P, Roussel AM, Favier A. Superoxide Dismutase Activity and Zinc Status: a Study in Animals and Man. J Nutr Med. 1992 Jan 1;3(1):13-26.

34. Song $\mathrm{Y}$, Leonard SW, Traber MG, Ho E. Zinc Deficiency Affects DNA Damage, Oxidative Stress, Antioxidant Defenses, and DNA Repair in Rats. J Nutr. 2009 Sep;139(9):1626-31.

35. Fukai T, Ushio-Fukai M. Superoxide Dismutases: Role in Redox Signaling, Vascular Function, and 
World Nutrition Journal vol.1 No. 1 July 2017 http://dx.doi.org/10.25220/WNJ.V01i1.0008

Diseases. Antioxid Redox Signal. 2011 Sep

15;15(6):1583-606. 